\title{
English Conversation Teaching by Pair-work Technique for The First Year English Majored Students
}

\author{
Muhammad Dalimunte \\ State Islamic University of North Sumatera (UINSU), Medan, Indonesia \\ muhammaddalimunte@uinsu.ac.id
}

\begin{abstract}
This study discusses about English conversation teaching by pair-work technique for the firts year English majored students. This study uses Classroom Action Research. It can be used to know the improvement of teachers' activity and students' ability after a particular technique applied. The research findings denoted that pair-work technique can attract the students' motivation to take part in language teaching and improve their ability at speaking, It can seen from the improvement of students' activities from cycle one to cycle two $(82,5 \%$ of the students took part in the teaching -learning process or at level 3,3,good category to $91,25 \%$ or at the level 3,65, good category in cycle two, and the improvement of their scores was 7 students (21,9\%) got score 70 up in pre cycle, 29 students (90,6\%) in cycle one and 32 students (100\%) in cycle two. It can be stated that the pair-work technique is appropriate to apply in teaching speaking.
\end{abstract}

Keywords : English conversation; teaching; technique; student

\section{Introduction}

A Teacher's thought about the teaching and learning process will certainly have impacts on the way he teaches. In recent years, language teaching has been focused on the learning process rather than the teaching of the language. The emphasis is not only on linguistic competence of language learners but also on the development of the communicative ability. Learners need to learn how to use the language.

In terms of the language use, we found some undergraduate students who are still poor at spoken language even few of them finished their study, this phenomenon drives the writer to find out the alternative solution to overcome this problem. This problem might be able to overcome by applying appropriate language teaching technique. One of the techniques is pairwork technique. In teaching speaking, the lecturer should be able to bring students to use the target language naturally. In pair-work activity students have opportunity to explore ideas by using the target language. The lecturer's role is as a facilitator during the class taking place, the classroom activity is the learners - centered activity.

We may be in one point of view that a good English lecturer should not only master the subject matter but also he should be able to create a good classroom atmosphere. A good classroom atmosphere means an attractive teaching process which are all students taking part in the process of teaching-learning. The common problem of language learner is the use of English in spoken language. An ideal teaching conversation is Teacher Talk Time (TTT) should be less than Students Talk Time (STT) because the students need more opportunity to use the target language than the teacher does, this is what we called learners- centered activity. This research discussed about : i) How is the implementation of pair-work technique in Speaking class?, ii) How is the classroom atmosphere s when the pair-work technique being applied?, iii) How is the students' ability at speaking after being taught by applying pair-work technique?. It is hoped that this research finding can be a consideration for English speaking Instructors as the alternative technique for English speaking class. 


\section{Review of Literature}

In communication process, language is as a media for people to express ideas both in written and spoken language. Language is a formal system of signs governed by grammatical rules of combination to communicate meaning. This definition stresses the fact that human languages can be described as closed structural systems consisting of rules that relate particular signs to particular meanings (Bloomfield, 1914). There are some elements of speaking should be mastered by language users:

1. Connected speech: effective speakers of English need to be able not only to produce the individual phonemes of English, but also to use fluent connected speech. In connected speech sounds are modified, omitted, added, or weakened. It is for this reason that we should involve students in activities designed specifically to improve their connected speech.

2. Expressive devices: native of English change the pitch and stress of particular parts of utterances, vary volume and speed, and show by other physical and non verbal means how they are feeling. The use of these devices contributes to the ability to convey meaning. They allow the extra expressions of emotion and intensity, students should be able to deploy at least some of such supra segmental features and devices in the same way if they are to be fully effective communicators.

3. Lexis and grammar: spontaneous speech is marked by the use of number of common lexical phrases, especially in their performance of certain language function. Teachers should therefore supply variety of phrases for different functions, such as: greeting, agreeing and disagreeing.

4. Negotiation language: effective speaking benefits from the negotiatory language we use to seek clarification and to show the structure of what we are saying (Harmer, 2002:269).

We often need ask for clarification when we are listening to someone else talks. Speaking is not only having amount of vocabularies and knowing the grammatical structures, but also mastering all elements of speaking above. In the other words, the elements of speaking are necessary for fluent oral production, distinguishes between two aspects - knowledge of 'language features', and the ability to process information on the spot, it means 'mental/social processing (Harmer, 2001). The first aspect, language features, necessary for spoken production involves, according to Harmer, the following features: connected speech, expressive devices, lexis and grammar, and negotiation language.

In order to wage a successful language interaction, it is necessary to realize the use of the language features through mental/social processing - with the help of 'the rapid processing skills', as Harmer (2001: 271) calls them 'mental/social processing' includes three features - language processing, interacting with others, and on-the-spot information processing. Again, to give a clearer view of what these features include, here is a brief explanatory: - language processing - processing the language in the head and putting it into coherent order, which requires the need for comprehensibility and convey of meaning (retrieval of words and phrases from memory, assembling them into syntactically and proportionally appropriate sequences); - interacting with others - including listening, understanding of how the other participants are feeling, a knowledge of how linguistically to take turns or allow others to do so; - on-the-spot information processing - i.e. processing the information the listener is told the moment he/she gets it. 
The other ideas from Brown notes the illocutionary competence as functional aspects 'pertaining to sending and receiving intended meanings' while sociolinguistic aspects of pragmatic competence relate to 'such considerations as politeness, formality, metaphor, register, and culturally related aspects of language' (Brown, 1994:229).

Communicative competence really deals with the students' achievement using the language in daily communication. The writer can say that most students have more difficulty in speaking ability than the others. Speaking skill needs knowledge of grammar, vocabulary, pronunciation of the language and the capability of applying them in speaking. The communicative ability can be specified into four components such Mc Namara cited:

a. Grammatical or formal competence, which covered the kind of knowledge (of systematic of grammar, lexis, and phonology) familiar from the discrete point tradition of testing.

b. Sociolinguistic competence, or knowledge o rules of language use in term of what is a appropriate to different types of interlocutors, in different setting, and on different topics.

c. Strategic competence, or the ability to compensate in performances for incomplete to imperfect linguistic resources in a second language; and

d. Discourse competence, or the ability to deal with extended use of language in context (2000:18).

The four components above show that the communicative competence needs a large insight in addition to mastering the rules of language. Moreover Harris says speaking is a complex skill requiring the simultaneous use of a number of different abilities which often develop at different rates. Either five components are generally recognized in analysis of the speech process:

1. Pronunciation including the segmental features-vowels and consonants - and the stress and intonation patterns.

2. Grammar

3. Vocabulary

4. Fluency.

5. Comprehension. For oral communication certainly requires a subject to respond to speech as well as to initiate it (Harris, 1969: 82).

These components are important to emphasize by speaking instructor in the process of teaching-learning in the classroom.

\section{Research Methodology}

The research design of this research is Classroom Action Research, This design is meaningful to know the improvement of teachers' activity and students' ability after a particular technique applied. It was done to know if pair-work technique was effective to increase the students' ability at oral communication. The data analysis used descriptive quantitative approach. The Procedures of Classroom Action Research (CAR) applied consisting of two cycles which each cycle consisted of Planning, Action, Observation and Reflection: 


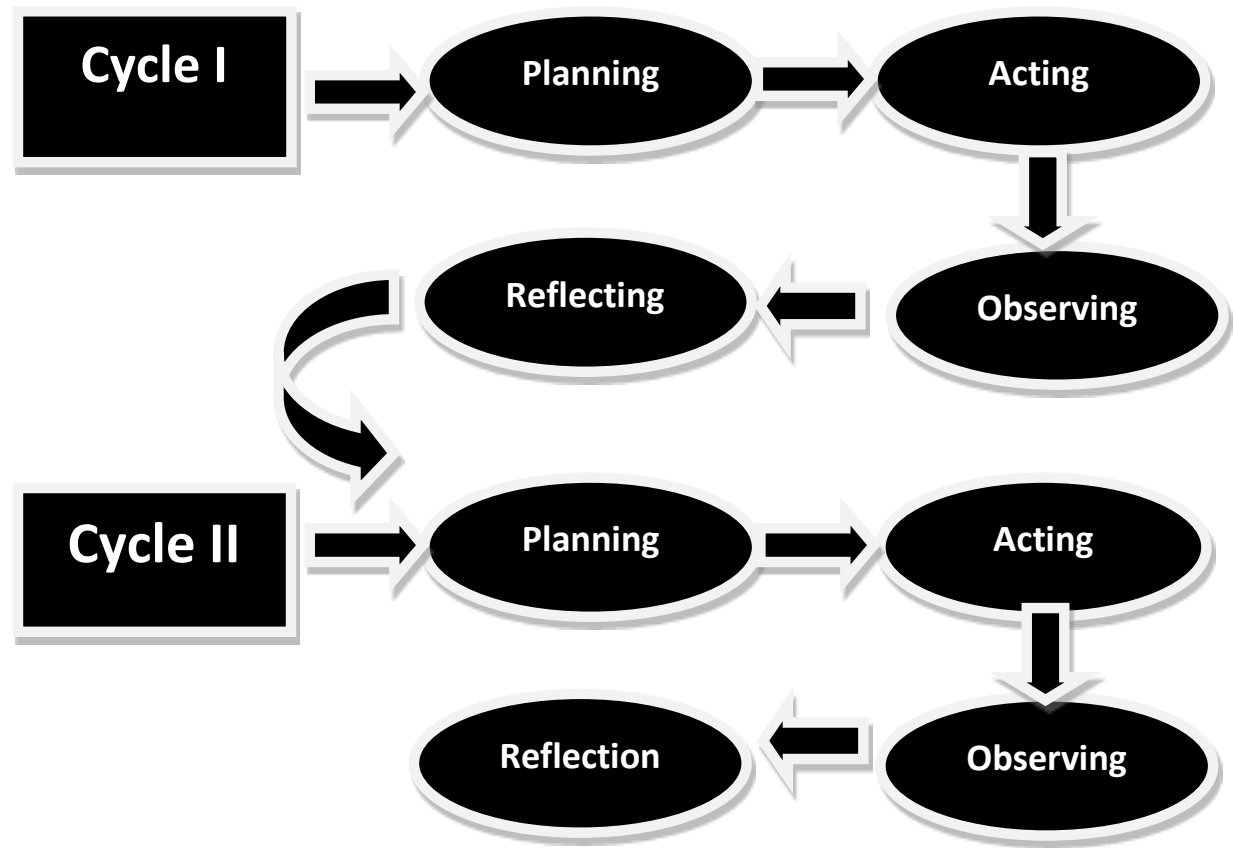

The instruments for data collection were used base on the data needed in this research. The data used in this research were qualitative and quantitative data. The qualitative data were the students' ability at speaking before and after being conducted the treatments, the qualitative data were the description of class cativities. The following instruments were used in this research:

1. Oral Test. The scenario and questions were used to find out the data about the students' ability at speaking English.

2. Tape recorder. It was also used to record students' answer of the questions given in the test. This record was used to reconfirm the scores given in the oral test.

3. Observation sheets. The observation sheets were used to see the lecturer's and students' activity in the classroom.

4. Interview sheet. It was used to find out the data about the students' problem in Oral communication and their responds on the strategy applied in the classroom.

5. Document. Any related document was needed, such as number of students in one class, curriculum used in the department etc.

6. Diary notes. It was used to note if there is necessary information needed to complete the data of this research.

The techniques for data collection were; observing, interviewing, Noting class activities and Testing. The components of the oral test which evaluated are based on the theory of David Harris. The components are:

1. Pronunciation (including the segmental features vowel and consonants and the stress and the intonation patterns )

2. Grammar

3. Vocabulary

4. Fluency ( the case and the speed of the flow speech )

5. Comprehension. These component are stated by Harris (1977:81) 
The components of the speaking above were evaluated to define the level of students' ability at oral communication.

\subsection{Scoring system}

In scoring technique used analytic scale that categorized within four categories. Each category has five items and each item scores five, so the maximum score is 25 . To get the maximum score was multiplied with 5 (Harris, 1969:84).

\begin{tabular}{|c|c|c|}
\hline Aspects & Score & Description \\
\hline \multirow{5}{*}{ Pronunciation } & 5 & Have few traces of foreign accent. \\
\hline & 4 & $\begin{array}{l}\text { Always intelligible, though one is } \\
\text { conscious of a definite accent }\end{array}$ \\
\hline & 3 & $\begin{array}{l}\text { Pronunciation problem necessitate } \\
\text { concentrated listening and occasionally } \\
\text { lead to misunderstanding. }\end{array}$ \\
\hline & 2 & $\begin{array}{l}\text { Very hard to understand because of } \\
\text { pronunciation problems, must } \\
\text { frequently be asked to repeat. }\end{array}$ \\
\hline & 1 & $\begin{array}{l}\text { Pronunciation problems so severe as to } \\
\text { make speech virtually unintelligible. }\end{array}$ \\
\hline \multirow{5}{*}{ Grammar } & 5 & $\begin{array}{l}\text { Makes few (if any) noticeable errors of } \\
\text { grammar and word order. }\end{array}$ \\
\hline & 4 & $\begin{array}{l}\text { Occasionally makes grammatical } \\
\text { and/or word order errors which do not, } \\
\text { however obscure the meaning. }\end{array}$ \\
\hline & 3 & $\begin{array}{l}\text { Make frequent errors of grammar and } \\
\text { word order which occasionally obscure } \\
\text { meaning. }\end{array}$ \\
\hline & 2 & $\begin{array}{l}\text { Grammar and word order errors make } \\
\text { comprehension difficult. Must often } \\
\text { rephrase sentences and/or restrict him } \\
\text { to basic patterns. }\end{array}$ \\
\hline & 1 & $\begin{array}{l}\text { Errors in grammar and word order as } \\
\text { severe as to make speech virtually } \\
\text { unintelligible. }\end{array}$ \\
\hline \multirow[t]{4}{*}{ Vocabulary } & 5 & $\begin{array}{l}\text { Use of vocabulary and idioms is } \\
\text { virtually that of a native speaker. }\end{array}$ \\
\hline & 4 & $\begin{array}{l}\text { Sometime uses inappropriate terms } \\
\text { and/or must rephrase the idea because } \\
\text { of lexical inadequate }\end{array}$ \\
\hline & 3 & $\begin{array}{l}\text { Frequently uses the wrong words; } \\
\text { conversation somewhat limited } \\
\text { because of inadequate vocabulary. }\end{array}$ \\
\hline & 2 & $\begin{array}{l}\text { Misuse of word and very limited } \\
\text { vocabulary make comprehension quite } \\
\text { difficult. }\end{array}$ \\
\hline
\end{tabular}




\begin{tabular}{|l|l|l|}
\hline & 1 & $\begin{array}{l}\text { Vocabulary limitations so extreme as } \\
\text { to make conversation virtually } \\
\text { impossible. }\end{array}$ \\
\hline \multirow{5}{*}{ Fluency } & 5 & $\begin{array}{l}\text { Speed as fluent and effortless as that of } \\
\text { a native speaker. }\end{array}$ \\
\cline { 2 - 3 } & 4 & $\begin{array}{l}\text { Speed of the speech seems to be } \\
\text { slightly affected by language problem. }\end{array}$ \\
\cline { 2 - 3 } & 3 & $\begin{array}{l}\text { Speed and fluency are rather strongly } \\
\text { affected by language problems. }\end{array}$ \\
\cline { 2 - 3 } & 2 & $\begin{array}{l}\text { Usually hesitant; often forced into } \\
\text { silent by language limitations. }\end{array}$ \\
\cline { 2 - 3 } & 1 & $\begin{array}{l}\text { Speech is as halting and fragmentary } \\
\text { as to make conversation virtually } \\
\text { impossible. }\end{array}$ \\
\hline
\end{tabular}

\section{Research Finding}

The gathered data were analyzed by using descriptive analysis. The writer explained the scores gained by students in each cycle. It was done after the mean of students score computed by using the following formula (Hatch and Farhady, 1982: 55)

$$
\bar{X}=\frac{\sum \mathrm{x}}{\mathrm{N}}
$$

Notes:

$\bar{X} \quad:$ Mean

$\sum \mathrm{x} \quad:$ Sum of individual observation /students

$\sum \quad:$ Sum

$\mathrm{x} \quad$ : Individual score / individual observation

$\mathrm{N} \quad$ : The number of observations/students

The analysis of this research gives the mean scores, frequency distribution of students' score, histogram of students' scores and statistics of students' scores. This analysis is important to see easily the improvement of students' score from pre-cycle (before the class) to last cycle (after the class).

The analysis of the class percentage scores which got KKM (Minimum Completeness Criteria) (score 70) analyzed by using the following formula.

$$
\mathrm{P}=\frac{F}{N} \times 100 \%
$$

P: The class percentage

F: Total percentage score

$\mathrm{N}$ : Number of observations/students

The data found from the observation sheets were about the lecturer's and students' activities during the class took place, the data were analyzed by using the following formula. 


$$
\text { Score }=\frac{\text { Total score }}{\text { Maximum score }} \times 100 \%
$$

The percentage of students' ability from pre-test to post-test 2 was presented in the following analysis.

$$
P=\frac{y 1-y}{Y} X 100 \%
$$

P: percentage of students' improvement

$y$ : pre-test score

$y 1$ : post-test score 1

P: percentage of students' improvement

$$
P=\frac{y 2-y}{Y} X 100 \%
$$

$y$ : pre-test score

y2: post-test score 2 (Sudijono, 2001:43)

The research findings denoted that pair-work technique can attract the students' motivation to take part in language teaching and improve their ability at speaking, It can seen from the improvement of students' activities from cycle one to cycle two $(82,5 \%$ of the students took part in the teaching -learning process or at level 3,3 ,good category to $91,25 \%$ or at the level 3,65, good category in cycle two, and the improvement of their scores was 7 students $(21,9 \%)$ got score 70 up in pre cycle, 29 students $(90,6 \%)$ in cycle one and 32 students $(100 \%)$ in cycle two. It can be stated that the pair-work technique is appropriate to apply in teaching speaking.

The common problems of students in speaking are 1). Inhibition. The students were often inhibited about trying to say things in foreign language in the classroom: worried about making mistakes (grammar problem), fearful of criticism or loosing face, or simply shy of attention that their speech attracts. 2). Nothing to say. Even they were inhibited, they could not think of anything to say. 3). Mother tongue use. The students tended to switch code when they did not find a word to say something (vocabulary problem). This problem can be decreased by convincing them that reaching speaking ability needs long term process, the practice was the one way to master a language.

\section{Discussion}

It was found that the teaching-learning process in the application of Pair-work technique were in good atmosphere. The process of the technique attracted the students' interesting to take part in class activities.

An appropriate technique will affect on class activities. In teaching conversation for instance, Traditional teaching technique will lead students to be good listeners where Students Talk Time (STT) tend is less than Teachers Talk Time. In recent years, language teaching has been focused on learning process rather than the teaching of the language. Pair-work technique as one of the current techniques could bring the students felt interesting and enjoyable to take part in the class activities so the communicative language skills were attained, this technique brought students to speak naturally. This is actually should be done by Language instructor, he should not teach students with structured dialogue because they will never own creativity and 
critical thinking, they do not have chance to build their own sentences. In speaking class, students should be given more time to practice, the lecturer takes role as a facilitator and gives feedback to the students' activity, if possible he can give praise on the students' achievement. In brief, gaining communicative competence needs long term process, so a good language instructor should make students feel free to express their ideas, they should not be given any correction on their utterances at the time they are speaking.

In teaching-learning process on speaking class, a good atmosphere in classroom can influence the students' wishes to take part in class activity. An appropriate technique will affect class activity. In teaching Speaking for instance, traditional teaching technique will lead students to be good listeners (teacher- centered) where Students Talk Time (STT) is less than Teachers Talk Time (TTT). In recent years, language teaching has been focused on learning process rather than the teaching of the language. Pair-work technique is one of the alternative ways to create a live atmosphere of language teaching where the students get more opportunity to practice the target language with their classmates.

\section{Conclusion}

The increasing of speaking skills needs long term process because there are some components should be mastered by language learners if they want to achieve speaking competence, the components are; 1) Pronunciation including the segmental features-vowels and consonants - and the stress and intonation patterns, 2) Grammar, 3) Vocabulary, 4) Fluency and 5). Comprehension.

The ability of mastering the components of speaking skills above leads a speaker to be good speech producer. The role of Instructor should be as facilitator in order the students have more opportunity to practice the target language and he should focus on the learning process rather than the teaching of the language. The emphasis is not only on linguistic competence of language learners but also on the development of the communicative ability because the learners need to learn how to use the target language in real life situation. Pair-work technique could bring the students to get more practice the target language in speaking class.

\section{References}

Bachman, L., F. 1990. Fundamental Considerations in Language Testing. Oxford: Oxford University Press.

Bloomfield, Leonard.1914. An introduction to the study of language. New York: Henry Holt and Company.

Brown, G., Yule, G. 1991. Teaching Spoken Language. Cambridge: Cambridge University Press

Brown, H. Douglas. 1994. Principles of language learning and teaching. $3 \mathrm{rd}$ edition. Englewood Cliffs, NJ: Prentice Hall Regents.

Canale, M. and Swain, M.1980. Theoretical bases of communicative approaches to second language teaching and testing. Applied Linguistics.

Cummins, J. (1979) Linguistic interdependence and the educational development of bilingual children. Review of Educational Research .

Cummins, J. (1980) The entry and exit fallacy in bilingual education. NABE Journal 4.

Harmer, J. 2001. The Practice of English Language Teaching. England: Longman. 
Harris, David P. 1977, Testing English as Second Language. New York : Georgetown University

Harris, David P. 1969, Teaching English as a second Language. New York : Georgetown University

Hatch \& Farhady. 1982. Research Design and Statistics for Applied Linguistics, New York : Newbury House Publisher:

Hymes, DH. 1972. On Communicative Competence

Mc Namara, Tim. 2000. Language Testing. New York: Oxford University press.

Revell, J. 1991. Teaching Techniques for Communicative English. Macmillan Education Ltd.

Sidijono,Abas. 2001. Pengantar Statistik Pendidikan. Jakarta: Raja Grafindo Persada 